\title{
Szabó-Balogh Virág
}

Szegedi Tudományegyetem Bölcsészettudományi Kar, Neveléstudományi Doktori Iskola

\section{Autizmus: az örök kirakó?}

Az autizmus fogalma a gyermekpszichiátriában Leo Kannertól (1946) és Hans Aspergertól (1944) származik, akik az autisztikus spektrumzavar két altípusát egymástól függetlenül îrták le. Az elmúlt közel nyolc évtized alatt számos kutató igyekezett felderiteni, mi is igazából az autizmus, mi okozza, mire számithatunk, ha egy autista személlyel lépünk kapcsolatba, mit tehetünk, hogy egy autizmussal éló hétköznapjait könnyebbé tegyük. Sokan sokféle megközelítést alkalmazva jutottak egyre közelebb a válaszhoz, azonban a mai napig nem került még helyére a kirakó minden darabja. Jelen cikkben az eddig napvilágot látott releváns „, darabkákat” igyekszem bemutatni, fókuszálva az alapvetố jellegzetességekre és az intervenciós lehetóségekre.

A z orvostudomány jelenlegi álláspontja szerint az autizmus a pervazív fejlődési zavarok egyike, az egész személyiséget érinti, „nem megkésett, hanem eltérő jellegü fejlődés" (Jordan, 2007). Idegrendszeri fejlődési zavar, melynek eredményeként a viselkedés egyes területein sérülés tapasztalható, ezek egy része humánspecifikus. Ilyen a nyelvhasználat, a mentalizációs képesség és a reciprocitáson alapuló kommunikáció. Mivel autizmusban a viselkedés szelektíven sérült, vélhetően a háttérben meghúzódó mentális rendszerek is szelektív sérülést mutatnak. Ezért az autizmus kutatása a viselkedést szervező kognitív mechanizmusok megértését is szolgálja (Baron-Cohen és Bolton, 2000).

Az első operacionalizált meghatározást a DSM (Diagnostic and Statistical Manual of Mental Disorders) harmadik kiadásában (DSM III.; APA, 1980) találhatjuk, ekkor a meghatározás döntően a szociális és kommunikációs tünetek sérülésére fókuszált. Később ennek revíziója, a DSM IV. (APA, 1994), illetve az ICD-10 (WHO, 1990) mint pervazív fejlődési zavart határozta meg. Három kritikus terület sérülését írták le (melyet Wing-féle triászként is megtalálhatunk számos szakirodalomban): a szociális, a kommunikációs képesség, valamint az érdeklődés, a viselkedéstervezés-szervezés területére jellemző repetitív magatartást, sztereotipitást (Lai, Lombardo és Baron-Cohen, 2014). Megnyilvánulásában nagymértékü variáció tapasztalható a járulékos zavarok, az életkor, az IQ, továbbá az autizmus súlyossága és egyéb individuális tényezök terén, ezért Wing megalkotta az autisztikus spektrum, illetve az autisztikus spektrumzavar fogalmát, ahová a gyermekkori autizmuson kívül például az atípusos autizmus is tartozik (Győri, 2003).

A legutóbbi, 2013-as kiadás szerint a DSM V. az autizmus spektrumzavar fogalmát altípusok megkülönböztetése nélkül írja le, valamint a fentebbi triászt újra átgondolva az alábbi diádba foglalta a vezető tüneteket: szociális kommunikáció és interakció nehezítettsége, valamint az érdeklődés, a viselkedéstervezés-szervezés területére jellemző beszükült, repetitív magatartás, sztereotipitás $(A P A, 2013)$.

Mivel az autizmus spektrumzavar igen széles, nagyok az egyéni különbségek. Ugyanakkor az autizmussal élő személyek többségére jellemzőek az alábbiak. A szociális interakciók zavara markáns jellegzetesség, mely a többi személyhez füződő viselkedési, 
érzelmi viszonyulás minőségi és mennyiségi beszűkülését jelenti (Győri, 2012). A kötődés részleges (vagy teljes) hiánya, az érzelmek kifejezésének, észlelésének sérülése alapvető. Az autizmussal élők gyakran nem kezelik személyként még a közelükben élő embereket sem, serdülö-, valamint felnőttkorban többnyire nem képesek jól müködő partneri viszonyt kialakítani. A szociális kommunikációra jellemző a nyelvi kommunikáció zavara, esetleg hiánya, gyakran már a preverbális kommunikációban megmutatkozva. A zavarok lehetnek prozódiai, szemantikai, szintaktikai, leggyakrabban pragmatikai jellegüek, ritkábban fonológiai zavar is elöfordul (Rommelse, Geurts, Franke, Buitelaar és Hartman, 2011). A funkcionális értelemben vett beszédkészséget az autista gyerekek közel fele nem képes elsajátítani, sokan egyáltalán nem rendelkeznek nyelvi készségekkel (Dawson és Castelloe, 1992; Rutter, 1966), gyakran a metakommunikáció is sérülést mutat. Verbalitással rendelkező társaik pedig sajátságos módon és stílusban fejezik ki magukat. Beszédük jellegzetes, szókincsük szegényes, túlzó módon általánosítanak, valamint a szintaxis területén ingadozó a szabályalkalmazásuk. Problémás a névmáshasználat (pl. „én” helyett a „te” személyes névmás használata), jellemző az idioszinkráziát vagy neologizmát használó beszéd, amikor egy szokványos szót szokatlan módon használnak, vagy egy nem létező, saját maguk alkotta szóval fejeznek ki valamit; illetve a sztereotip beszéd (pl. az érdeklődésnek megfelelő téma hozatala állandóan) és az echolália, egy másik személy beszédének az utánzása (Rommelse és mtsai, 2011). Az echolalia (Frith, 1998), a gyakran megértés nélküli ismétlés lehet azonnali vagy késleltetett. E jelenség mutat rá, hogy az autizmussal élők nem kerülik a kontaktust, csak a rendelkezésre álló eszközeik korlátozottak. A vicc, az irónia, az átvitt értelmű kifejezések, az elvont és a kétértelmű szavak használata és értelmezése számukra problémát okoz (Happé, 1993; Peeters, 1997), mindent szó szerint vesznek. A dialógus során az autisták azért nem ismerik fel a tévesztés lehetőségét, mert szóhasználatukat - szemben a tipikusan fejlődőkével - a szituáció nem árnyalja (Frith, Morton és Leslie, 1991). Az autisták kommunikációjában megjelenő sajátosságok Janetzke (1995) szerint: korlátozott kommunikációs készség és indíték, szokatlan non-verbális kommunikáció, feltűnő beszédmód (prozódia, hangszín, ritmus), korlátozott beleélőképesség, kevés vokális intonáció. A szociális jelleg hiánya domináns jegy, döntően ugyanis nem folytatnak kölcsönösséget igénylő dialógust (Bailey, Phillips és Rutter, 1996; Lord és Rutter, 1994). Ugyanakkor egyes autizmussal élők képesek sikeresen dialógusok lefolytatására is. A beszélt nyelv mellett általában az írásbeli kifejezés is nehezített (Asberg, Kopp, Berg-Kelly és Gillberg, 2010). Autizmusban a nyelvi folyamatokért felelős kérgi területek közti információáramlás, integráció, szinkronicitás gyengébb, csökkent müködés tapasztalható a bal agyféltekén, mely a korai nyelvelsajátításban játszik döntő szerepet (Rommelse és mtsai, 2011). A képzeleti müködésre, a viselkedéstervezésre-szervezésre és érdeklődésre jellemző a merev, szűk körü, sztereotip megnyilvánulás, az érdeklődési körön kívül eső jelenségek gyakori ignorálása (Györi, 2012).

Epidemiológiai szempontból napjainkban 0,62-0,70 százalékos, nem ritkán 1-2 százalékos prevalenciáról számolnak be áttekintő tanulmányokban (Lai és mtsai, 2014) Az autizmus gyakorisága látszólag nő, az egyre magasabb előfordulási arányt azonban az alkalmazott kritériumok bővülése és a hatékonyabb diagnosztikus eszközök magyarázhatják. A nemek szerinti megoszlás autizmus esetében 3-5:1 arányt mutat a férfiak javára, mely az autisztikus spektrumzavarok figyelembevétele esetén még fokozottabban feléjük tolódik el (Lai és mtsai, 2014). Ez több genetikai hipotézist is felvet, az X-kromoszóma rendellenességet, a nemhez kötött öröklődést, valamint a genetikai imprinting lehetőségét (Györi, 2012). Továbbá érdemes megemlíteni: elképzelhető, hogy az autizmussal élő nők aránya alulbecsült, magasan funkcionáló nők dignózisa későbbi életkorra tolódik el, vélhetően jó kompenzációs stratégiák miatt csak később, amikor már több kognitív, viselkedései tünet lép fel, kerülnek szakemberhez (Lai és mtsai, 2014). 
Kialakulásában heterogén okok játszanak szerepet, legtöbb esetben a genetikai tényezők a leglényegesebbek, de több mint 60 perinatális és neonatális tényezőt vizsgáltak már, így például rizikótényezőként összefüggést találtak az autizmus kialakulásával a köldökzsinór-komplikációk, alacsony 5 perces Apgar-érték, táplálási nehezítettség, vércsoport-összeférhetetlenség esetében (Gardener, Spiegelman és Buka, 2011). A poligénes alapmechanizmus egyértelmübb az esetek döntő többségében, szemben a mendeli öröklésen alapuló monogénes elmélettel (Geschwind, 2011). Kérdéses még azonban, pontosan mely kromoszómák érintettek. Mára már minden kromoszómán mutattak ki az autizmussal összefüggő géneket, ám egyik esetében sem állítható, hogy az autizmus spektrumzavarok tüneteivel együttjárás fedezhető fel (Győri, 2012). Exogén faktorok is megjelenhetnek, melyek a magzat fejlödését az autizmus irányába terelhetik, ilyenek lehetnek egyes korai vírus-, illetve baktériumfertőzések, illetve a perinatális oxigénhiány is (Baron-Cohen és Bolton, 2000). Autizmussal élö gyermekek szülei magasabb arányban tehetségesek, mutatnak érdeklődést és dolgoznak információ-technológiai területen, mint más szülök (Roelfsema és mtsai, 2012). Ugyanakkor nem nyert bizonyítást az a hipotézis, miszerint az oltások (pl. MMR) beadása autizmust okozna (Lai és mtsai, 2014).

Az esetek 70 százalékában járulnak további zavarok az autizmus mellé. Fejlődési zavarok közül többek között az értelmi fogyatékosság az esetek közel 45 százalékában, ADHD 30-40 százalékban, továbbá tic-zavarok, motoros abnormalitás, nyelvi fejlődési zavarok. Általános egészségügyi állapotot befolyásoló tényezők közül az epilepszia 8-30 százalékban, gasztrointesztinális probléma 9-70 százalékban, alvászavarok 50-80 százalékban. Pszichiátriai zavarok közül a szorongás 40-50 százalékban, depresszió 12-70 százalékban, személyiségzavarok közül a kényszeres személyiségzavar 19-32 százalékban, a skizoid személyiségzavar pedig 21-26 százalékban (Lai és mtsai, 2014). Mindez hosszabb távon jellemző, így például felnőtt korú autizmussal élőknél a hangulati zavarok és a szorongás egyaránt közel 50 százalékban jellemző (Happé és Charlton, 2012).

Mai tudásunk szerint az autizmus nem tranziens jelenség, a sérült személyt egész életen át jellemzi, fejlesztéssel támogatható az érintett személy, de teljes gyógyulás nem várható. Azonos nemü és korú egészséges személyekhez viszonyítva 2-8-szor magasabb mortalitási rizikó tételezhető fel autizmusban, melynek oka általában egyéb, az autizmushoz társuló egészségügyi tényező (Woolfenden, Sarkozy, Ridley, Coory és Williams, 2012). Önálló életvitelre, párkapcsolatra, hivatalos munkavégzésre kevesen (22-42 százalékuk) képesek, ugyanakkor fontos tény, hogy a felnőtt korú autizmussal élőkről jóval kevesebb információval rendelkezünk, mint a kiskorúakról, kevés tudásunk van tüneteikről, életminőségükről, képességeikről (Happé és Charlton, 2012).

A járulékos jellegzetességek sokszor egyenetlen képességprofilt eredményeznek, nehezítve ezzel a diagnosztikát is. Bizonyos területeken szélsőségesebb ingadozást mutathat az autizmussal élő személy a képességek vonatkozásában, így egyes esetekben a képességek megörzött szigeteiröl ('islets of abilities'). Néhány autizmussal élö (többnyire a magasan funkcionálók ['high functioning']) átlagon felül is teljesíthet egyes területeken, öket savant-szindróma kifejezéssel is illetik olykor. Az 'idiot savant' személy megnevezés arra utal, hogy gyakran átfogó intellektuális deficit mellé társul valamely egyedi, különlegesen kiemelkedő képesség. Autizmusban ezek a képességek erősen fókuszáltak, többnyire inkább mechanisztikus, kevéssé kreatív jellegüek (Győri, 2012). A perceptuális képességek területén jelentkezhet például az atipikus müködés, ilyenkor hajlamosak afunkcionális részleteket használni tájékozódási pontul. Ez olykor személyes, akár társadalmi előnyt is jelenthet (Happé és Vital, 2009), ekkor autisztikus adottságról beszélhetünk, elsősorban a mechanikus emlékezetet, a téri-vizuális képességeket, az aritmetikai müveletek fejben történő elvégzését, valamint a zenei és a rajzolási képességeket érinti (Győri, Gy. Stefanik, Kanizsai-Nagy és Balázs, 2002). 
Az intelligencia mérésének eredményei alapján beszélhetünk alacsony és magas szinten funkcionáló autizmussal élő személyekről. Ennek meghatározása során különös körültekintés ajánlott, mivel föként hat éves kor elött drámai változások is bekövetkezhetnek az intelligencia fejlődésében, éppen ezért az autisták tanítása kitüntető figyelmet kíván (Dawson, Souliéres és Mottron, 2007). Lényeges továbbá az intellektuális képességekre vonatkozóan, hogy többnyire jelentős különbség van a verbális és a perceptuális képességek között (Deary, Penke és Johnson, 2010).

A diagnosztizálás különös alaposságot igényel, egyrészt a járulékos jellegzetességek, esetlegesen társuló komorbid állapotok, másrészt a korai életkori érintettség miatt (a tünetek 3 éves kor előtt megjelenése, ennek visszakövetése szükséges). Nemzetközi gyakorlatban az alábbi szürő eljárásokat használják (Lai és mtsai, 2014): Kisgyermekeknél (36 hónapos kor alatt) CHAT (Checklist for autism in toddlers), ESAT (Early screening of autistic trait), M-CHAT (Modified checklist for autism in toddlers), ITC (Infant toddler checklist), Q-CHAT (Quantitative checklist for autism in toddlers), STAT (Sreening tool for autism in children aged 2 years), melyek viselkedéses tünetlisták, szürőtesztek, illetve megfigyelési helyzetek. Nagyobb gyerekeknek, serdülöknek SCQ (Social communication questionnaire), SRS (Social responsiveness scale), SRS-2 (Social responciveness scale, second edition), CAST (Childhood autism screening test), ASSQ (Autism spectrum screening questionnaire), AQ (Autism spectrum quotient, childhood and adolescent versions), melyek 2-16 év közöttieknek (életkoronként bontva) készült szürötesztek, kérdőívek, skálák. Felnőtteknek AQ (Autism spectrum quotient, adult version), RAADS-R (The Ritvo autism Asperger diagnostic scale-revised), melyek 16, 18 éves kor fölöttieknek készült kérdőívek. Diagnosztizáláshoz strukturált interjúhelyzet szükséges, az alábbi eszközöket alkalmazzák: ADI-R (The autism diagnostic interview-revised) 2 éves mentális kor fölött, DISCO (The diagnostic interview for social and communication disorders), amely minden életkorban használható, valamint 3Di (The developmental, dimensional, and diagnostic interview) 2 év fölött. Valamint megfigyelési helyzetben is felmérik a gyermekeket, melynek során 12 hónapos kor fölött az ADOS (The autism diagnostic observation schedule, Autizmus Diagnosztikus Obszervációs Séma; Lord, Rutter, Dilavore és Ris, 1999), ADOS-2 (The autism diagnostic observation schedule, second edition), illetve 2 éves kor fölött a CARS (Childhood autism rating scale), CARS2 (Childhood autism rating scale, second edition) használatos. Előbbi interakciós helyzetben jelent megfigyelést, utóbbi pedig a gondozóval (szülővel) készített osztályozó skála a gyermek viselkedése alapján (Lai és mtsai, 2014). Hazai gyakorlatban a fentebb elmített ADOS és ADI-R mellett a PEP-3 (Psychoeducational Profile-Revised, TEACCH; Schopler, Reichler, Bashford, Lansing és Marcus, 1990), illetve a TTAP (TEACCH Transition Assessment Profile; Mesibov, Thomas, Chapman és Schopler, 2007) általános fejlettségi szintet és képességeket felmérő teszteket használják mint autizmus-specifikus teszteket.

Az autizmust számos kognitív elmélet igyekszik magyarázni, köztük a naiv tudatelméleti zavar hipotézise. Az elmélet Baron-Cohen, Leslie és Frith (1985; magyarul lásd: Györi, 2003) nevéhez köthető. A kutatók feltételezik, hogy az autizmussal élö gyermekek esetében sérült a naiv tudatelmélet ('naive theory of mind', röviden ToM), azaz a mentalizáció, mentális állapottulajdonítási képesség. Korlátozott mértékben képesek tehát maguknak, illetve másoknak mentális állapotot tulajdonítani az autista személyek, ami azt eredményezi, hogy nehezen tudják (vagy egyáltalán nem képesek) a cselekedeteket értelmezni, bejósolni, szándékot előre jelezni. Sérült a metakommunikatív jelzések felismerése is, a fantáziajátékok, a deiktikus kifejezések használata, vagyis a helyes névmáshasználat, a nyelvi szimbólumok megértése és alkalmazása. E kognitív sérülés a szerzők szerint univerzális az autizmusban és specifikus a zavarra nézve, valamint primer kognitív sérülés, továbbá minden tünet-területet képes magyarázni. A naiv tudatelmélet normál fejlődés esetén 18-24 hónapos korig a mintha-játék formájában már megnyilvá- 
nul. A mentálisállapot-tulajdonítási képesség implicit és explicit szinten egyaránt zajlik, elöbbi segítségével tudjuk nyomon követni mások szándékait, míg az explicit szint teszi lehetővé számunkra, hogy tudatában legyünk annak, hogy a saját és a mások mentális tudatállapotai különbözőek, ez utóbbi humánspecifikus képesség (Frith és Frith, 2012). A fejlődés és életkor elörehaladtával a hamisvélekedés-tulajdonítási feladatok alkalmasak a naiv tudatelmélet fejlettségének vizsgálatára. Wimmer és Perner (1983) kidolgozta az úgynevezett Sally-Anne tesztet (hamis vélekedés teszt) annak vizsgálatára, hogy az autista gyerekek rendelkeznek-e tudat-teóriával. További hasonló feladatok még a Smarties teszt (Gopnik és Astington, 1988), továbbá a Reading The Mind in The Eyes Test (Baron-Cohen, Wheelwright, Hill, Raste és Plumb, 2001).

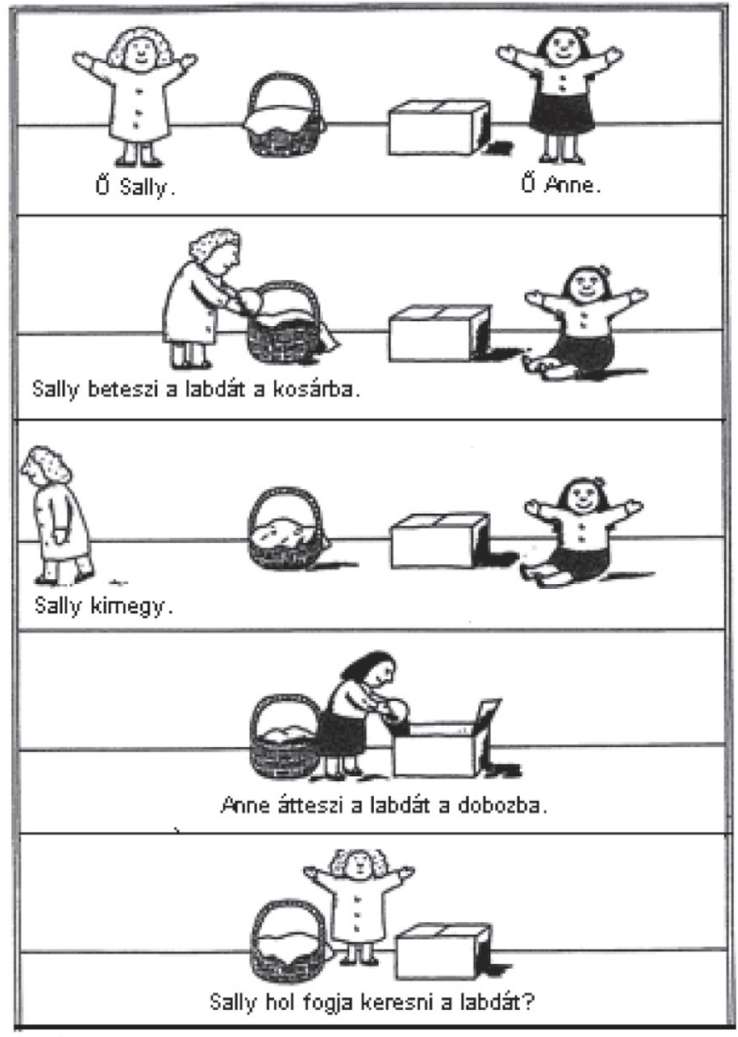

1. ábra. Sally-Anne Test (Baron-Cohen, Leslie és Frith, 1985)

Autizmus esetén a zavar a mentális reprezentációk (mentális állapotok) megértésére korlátozódik. E zavar azonban nem az általános kognitív képességek elmaradásának tulajdonítható, ugyanis a mentális korban illesztett neurotipikus és Down-szindrómás gyerekek többsége képes volt a hamisvélekedés-tulajdonítási feladatok megoldására Baron-Cohen és munkatársai (1985; magyarul ld. Győri, 2003) vizsgálatában. Későbbi vizsgálatokban autizmussal élők közül az első fokú mentalizációs feladatok megoldása többeknek, néhány személynek pedig a magasabb fokú mentalizációs feladatok megoldása sem jelentett lehetetlen feladatot (Györi, 2009). Ez arra enged következtetni, hogy azon autistáknál, akik jobb naiv tudatelméleti képességekkel rendelkeznek, esetleg késéssel érik 
be, illetve atipikusan müködik e képesség. Happé (1994b; magyarul ld. Győri, 2009) rámutatott, hogy azon viselkedéseknél figyelhető meg markáns sérülés, melyek mentális állapotot igényelnek, míg a ToM-kompetenciát (ToM, Theory of Mind, tudatállapot-tulajdonítás) nem igénylö viselkedések esetében nem jelentkezik a deficit. Ennek alapján tehát az autizmus egy disszociatív fejlődési sérülés, ahol a formális értelemben vett nyelv mechanizmusai közel épek, míg a kommunikatív funkciókért felelős rendszerek sérültek, háttértényezője pedig a naiv tudatelméleti fejlődés zavara lehet. Ugyanakkor vitatott a ToM-zavar univerzalitása, mivel az autizmussal élők 20-70 százaléka képes elsőfokú mentális állapot tulajdonítására. A ToM-müködés igen összetett, mozgósítja a memóriát, a közös figyelmi folyamatokat, komplex perceptuális müködést igényel, továbbá nyelvi és végrehajtó funkciók is szükségesek a megfelelő müködéshez, összefügg az érzelem-feldolgozással, empátiával, utánzással, müködésének sikere függ az idegrendszer érettségétől, valamint erősen formálják az elsődleges és másodlagos szocializáltságot szolgáló közegek (szülők, iskola), és fejleszthető oktatással (Korkmaz, 2011). Az agyban történő reprezentálódást tekintve mind explicit, mind implicit ToM-feladatvégzés során aktiválódik a mediális prefrontális kéreg, a temporális lebeny és a poszterior szuperior temporális sulcus (Frith és Frith, 2003), továbbá érintett az anterior cinguláris kéreg, az inferior parietális kéreg és a frontális lebeny (Brüne és Brüne-Cohrs, 2006). Erösen heterogén a magasan funkcionáló autizmussal élök populációja a ToM-képesség komplexitását tekintve. Vannak, akik használnak nem ToM-alapú kompenzációs stratégiát olyan helyzetekben, melyeket a hétköznapi emberek mentálisállapot-tulajdonítással oldanak meg. Megkülönböztethető verbálisan és nem verbálisan mediált tudatelméleti képesség, előbbi kevéssé, utóbbi azonban sikeresebb a társas viselkedés irányításában autizmussal élök esetében. A ToM-képesség stabilitása, az, hogy mennyire következetesen hoznak jó megoldást helyzetről helyzetre, szintén jelentős heterogenitást mutat (Györi, 2009).

A naiv tudatelméleti mechanizmusok többek között a szándékattribúció és a szándékfelismerés vonatkozásában lényegesek számunkra, melyek a kommunikációban központi jelentőségüek, így a párbeszédek sikerességét is befolyásolják. Baron-Cohen és Bolton (2000) a „végső közös ösvény” modelljükben foglalták össze mindazokat az okokat, melyek az autizmus hátterében vélhetően állnak. A számos különböző ok a modell szerint abban közös, hogy olyan agyi területeket károsítanak, melyek a kommunikációért, társas viselkedésért és játéktevékenységért felelősek, így a homloklebeny (tervezés), a limbikus rendszer (érzelmek), a kisagy (mozgáskoordináció), valamint a neurotranszmitterek közül a szerotinin emelkedett (30-40 százalékkal magasabb) szintje a leghangsúlyosabb. Ezen tényezők egymással kölcsönhatásban magas fokú multikauzalitást okoznak, ami az autizmus igen nagyszámú variációit hozza létre (Baron-Cohen és Bolton, 2000).

Összességében a naiv tudatelméleti zavar hipotézise részleges magyarázóerővel bír az autizmus tünettanára vonatkozóan. Önmagában nem ad elegendő empirikusan bizonyított magyarázatot a szociális és kommunikatív tünetek teljes körére, valamint lényeges, hogy további, a társas megismerést érintő mechanizmusok - például a közös figyelmi müködés - is sérülést mutatnak e zavarban (Györi, 2012).

Mindamellett, hogy a hétköznapok szintjén nyilvánvaló nehézséget okoz a legtöbb autizmussal élő számára az, hogy nehezen, kevésbé sikeresen képesek mások nézőpontjába helyezkedni, bizonyos aspektusból előnyt is hozhat ez az érintettek számára. Ezt a kérdést feszegette Happé és Vital (2009), akik több lehetőségben gondolkodnak. Egyrészt fordított korreláció tételezhető fel a szociális érdeklődés és a savant képesség, tehetség között. Másrészt ugyanez a folyamat képezheti az alapját az eredetiségnek, mind az autizmus, mind a savant képességek esetében. A tipikusan fejlödő gyerekek szociális fejlődésük során azzal, hogy egyre jobban részesévé válnak egy adott közösségnek, alkalmazkodva ahhoz, elvesztik kissé az egyedi kifejezési módot (gyermekrajzokra gondolva például nagyon hasonlóvá válik idővel a nap vagy a madarak ábrázolása). Ezzel 
szemben autizmusban megmarad az egyediség, eredetiség (Happé és Vital, 2009). Harmadrészt, ha másoknak nehezebben tud mentális állapotot tulajdonítani bárki, jellemzően a saját mentális állapotra való reflektálás is nehezített (Williams és Happé, 2009). Ez ismét kifejezett elönyt is jelent azon képességek számára, melyek implicit tanulás révén fejlődnek (Reber, 1976; Fletcher, Zafiris, Frith, Honey, Corlett, Zilles és Fink, 2005). Léteznek olyan készségek, melyek önreflektivitás nélkül müködnek jobban, például golfjátékosok teljesítményét rontja, ha tudásukat explicitté kell tenni játék közben, ha el kell magyarázniuk, hogyan tudják az optimális ütést elvégezni (Happé és Vital, 2009). Továbbá lényeges, hogy az alacsony szintü öntudatosság nagyon hasonló állapotként írható le, mint a flow-állapot (Csíkszentmihályi, 1990), amit így az autizmussal élők könnyebben érhetnek el, ez pedig egyfajta megerősítő, jutalmazó állapot, ami a tehetség kibontakozását segítheti (Happé és Vital, 2009).

A végrehajtó működési zavar hipotézise (Ozonoff, 1997) szintén az autizmus hátterét igyekszik megragadni. A végrehajtó müködések ('executive functions') a frontális lebenyhez köthetőek, melynek funkciói közé tartozik a tervezés, impulzuskontroll, a valóság monitorozása, az irreleváns válaszok gátlása, a munkamemória, a fluencia, valamint a kognitív flexibilitás, a gondolkodás és cselekvés rugalmasságának fenntartása (Rommelse, Geurts, Franke, Buitelaar és Hartman, 2011). Tehát minden kimenő viselkedés és ezek hátterét képező rendszer adaptív összerendezéséért, kontrolljáért felel a személyes cél elérése érdekében (Györi, 2012). Magasan funkcionáló autizmussal élők esetében is gyakori, hogy a hétköznapi rutinokhoz szükséges adaptív magatartás csupán limitáltan müködik (Happé és Vital, 2009). Az eredeti hipotézis kiindulópontja az, hogy a diád második területére jellemző sztereotip és repetitív viselkedések (melyek szociális jellegü zavarok is), a felnőttkorban szerzett frontálislebeny-sérültek tünettanában is megjelennek. Az autizmussal élők rosszabbul teljesítenek a végrehajtóműködés-teszteken, de eredményeik jól
Mindamellett, hogy a hétköznapok szintjén nyilvánvaló nehézséget okoz a legtöbb autizmussal éló számára az, hogy nehezen, kevésbé sikeresen képesek mások nézópontjába helyezkedni, bizonyos aspektusból elónyt is hozhat ez az érintettek számára. Ezt a kérdést feszegette Happé és Vital (2009), akik több lehetôségben gondolkodnak. Egyrészt forditott korreláció tételezhetófel a szociális érdeklódés és a savant képesség, tehetség között.

Másrészt ugyanez a folyamat képezheti az alapját az eredetiségnek, mind az autizmus, mind a savant képességek esetében. A tipikusan fejlödó gyerekek szociális fejlódésük során azzal, hogy egyre jobban részesévé válnak egy adott közösségnek, alkalmazkodva ahhoz, elvesztik kissé az egyedi kifejezési módot (gyermekrajzokra gondolva például nagyon hasonló-

vá válik idóvel a nap vagy a madarak ábrázolása). Ezzel szemben autizmusban megmarad az egyediség, eredetiség (Happé és Vital, 2009). Harmadrészt, ha másoknak nehezebben tud mentális állapotot tulajdonitani bárki, jellemzöen a saját mentális állapotra való reflektálás is nehezitett (Williams és Happé, 2009). Ez ismét kifejezett elónyt is jelent azon képességek számára, melyek implicit tanulás révén fejlödnek (Reber, 1976;

Fletcher, Zafiris, Frith, Honey,

Corlett, Zilles és Fink, 2005). 
elkülönülnek egyéb végrehajtó müködési zavart mutató szindrómáktól (például Tourette-szindróma). E feladatok végzése során föként a fronto-parietális területen tapasztaltak funkcionális mágneses rezonancia (fMRI) vizsgálatok során alulmüködést (Rommelse és mtsai, 2011). Az elmélet sikeresen képes magyarázni a repetitív viselkedéseket, valamint a szociális és kommunikatív területeken jelentkező egyes tüneteket, ugyanakkor sokáig problémát jelentett, hogy kevés adat utalt a végrehajtó müködés korai megjelenésére az autisztikus fejlődésmintázatokban (Györi és mtsai, 2002). További kérdés, mely funkciók érintettek legintenzívebben. Bár korántsem tisztázott, egyes adatok arra utalnak, hogy autizmusban a végrehajtó funkciókon belül a tervezési folyamat deficitje a vezetö tünet (Sinzig, Morsch, Bruning, Schmidt és Lehmkuhl, 2008).

A gyenge centrális koherencia vagy részletközéppontú feldolgozási stílus (Frith és Frith, 1991; Happé, 1994a) a járulékos jellegzetességek egy részét, az atipikus perceptuális képességeket, az autisztikus adottságokat képes magyarázni, összefüggésben a fentebb említett „helyi kapcsolatbőséggel” (Győri, 2012). A személy sajátos feldolgozási stílusára fókuszál az elmélet, mely a bejövő információ részletkénti feldolgozását feltételezi. Ugyanakkor a centráliskoherencia-zavar és a naiv tudatelmélet zavara kevés pozitív korrelációt mutat. Happé (1994b) megfogalmazásában azon autizmussal élők tudnak a naiv tudatelmélet sérülésére jó kompenzációs stratégiát kialakítani, akiknél kevésbé sérült a centrális koherencia. Az elmélet magyarázatot kínál a szigetszerü és savant képességekre, valamint az érdeklődés specifikált jellegére.

További alternatív hipotézisek szintén igyekeznek megmagyarázni az autisztikus tünetek bizonyos okait. Ilyen alternatív hipotézis a közös figyelem ('joint attention') és az érte felelős koordináló kognitív mechanizmusok korai sérülése, mely valóban az autizmus egy neurokognitív oka lehet, azonban számos esetben nem mutatható ki életkori közös figyelmi zavar, illetve hiány (Baron-Cohen, 1995; Gopnik és Wellman, 1994; Karmiloff-Smith, 1991). A másik elképzelés a figyelem korai életkorban megjelenő zavarát állítja középpontba (Burack, Enns, Stauder, Mottron és Randolph, 1997), és a kisagyi struktúrák fejlődési eredetü sérülését feltételezi. A korai utánzás hipotézise (Gopnik, Slaughter és Meltzoff, 1994; Gopnik, 1994) szerint a veleszületett korai utánzás sérülése áll az autizmus hátterében, azonban direkt bizonyítékok hiányában ez az elmélet sem képes kielégítő magyarázatot adni. A kontingenciadetekció és -preferencia hipotézise (Csibra, Gergely, Biro, Koos és Brockbank, 1999) szerint az autizmussal élő csecsemőknél egy alapvető preferenciaváltás csak részlegesen történik meg: a saját cselekvés és az azt követő ingerlés teljes kontingenciájának kereséséről a magas, de nem tökéletes kontingencia előnyben részesítésére való váltás tipikus fejlődés esetén 3 hónapos kor körül játszódik le (Győri, 2003). Ez lenne a naiv tudatelmélet kialakulásának előfeltétele. Tehát a preferenciaváltás részleges volta eredményezi a naiv tudatelmélet sérülését, illetve hiányát. Az elmélet azonban kevés kontrollált bizonyítékkal rendelkezik. Lényeges továbbá, hogy az autizmus hátterében bizonyos transzmitter-anomáliák is meghúzódhatnak (Happé, 1994b), így a dopamin-, szerotonin- és endogén-opiátok rendellenessége, melyekről azonban még nem tudunk eleget. Az agykéreg hálózatos múködését alapul véve konnekcionista modellezéssel számos autisztikus jellegzetességet vizsgáltak már (részletesen ld. Várnagy, Györi és Bérdi, 2011).

Az autisztikus zavarok megértéséért agyi képalkotó eljárásokkal (MRI; PET) és az agy szövettani elemzésével végzett vizsgálatok eredménye szerint autizmus esetében az agy különböző területei között a kapcsolódás módja és kiterjedése eltéréseket mutat a tipikusan fejlődőkkel szemben, a különböző agyterületek nincsenek kellő mértékben összehangolva (Fogassi, Gesierich, Rizzolatti, Rozzi, Chersi és Ferrari, 2005). A teljes agyméret megnövekedése 5-10 százalékban jellemzö (Freitag, Luders, Hulst, Narr, Thompson, Toga, Krick és Konrad, 2009), más eredmények szerint azonban az érintett gyermekek 15 százalékát microcephália jellemzi, míg gyakran írtak le normál agyméretet is (Rom- 
melse és mtsai, 2011). Legfrissebb kutatások szerint úgy tünik, attól függően jellemző autizmusban az átlagos agymérettől (fejkörfogat alapján következtetve) való pozitív vagy negatív irányú eltérés, hogy milyen életkorban vizsgáljuk az érintett személyt. Születéskor erösen csökkent, az első életévben megnövekedett, felnőttkorban pedig gyakran a normált megközelítő agytérfogat jellemző (Redcay és Courchesne, 2005).

Jelentős a központi idegrendszeri struktúrák és funkciójuk károsodása (Robbins, McAlonan, Muir és Everitt, 1997). A mediális temporális lebeny hipotézise szerint a limbikus rendszerhez tartozó struktúrák fokozott sejtsürüségének hátterében a neurális fejlődés szelektív lemaradása állhat, mely szociális diszfunkciókat okozhat autizmusban. A frontostriatális hipotézis szerint a struktúra dopaminerg rendszerének túlzott aktivitása felel az autizmusban jellemző repetitív és sztereotip viselkedésmintázatokért. Csökkent kapcsolat tapasztalható a frontális és poszterior kérgi terültek között, illetve az anterior cinguláris kéregben, míg a parietális-occipitális területek fokozott aktivitása jellemző vizuospaciális helyzetben (Minshew és Keller, 2010). A kisagyi-agytörzsi hipotézis szerint a kontrollszemélyekhez képest az autizmussal élökre csökkent kisagytérfogat jellemző. Érintett továbbá a bazális ganglion is (Várnagy és mtsai, 2011). Posztmortem vizsgálatok csökkent neuronszámot találtak a kisagy, az amygdala és a fusiform gyrus területén (Schuman, Noctor és Amaral, 2011).

Az agyban az idegsejtek rétegezettsége autizmussal élök esetében nem egymástól elhatároltan, hanem folyamatosan fut, és bizonyos helyeken oda nem tartozó idegsejtek szétszóródva helyezkednek el. Rizzolatti és munkatársai (Rizzolatti és Arbib, 1998) felfedezték az ún. tükör-neuronok létezését, melyek az idegekben lévő elektromos aktivitást adják tovább. A beszédért felelős Broca-területen is felfedezhetőek ezen idegsejtek. Az autizmusban jellegzetes nyelvi fejlődés, echolália kapcsán feltételezhető, hogy sérültek a „tükör-neuronok". Megfelelő müködése esetén a megfigyelő a megfigyelt személy cselekedeteit szemlélve képes felismerni annak szándékát. Amennyiben beigazolódik, hogy autizmusban a tükör-neuronok sérültek, bizonyítást nyer a fentebb részletezett naiv tudatelméleti deficit, miszerint az autizmussal élők nem képesek mentálisállapot-tulajdonításra. Fontos azonban megjegyezni, hogy az utóbbi években a tükör-neuron elképzelést számos kutatás cáfolta (Hickok, 2014).

Mielőtt a konkrétabb intervenciós lehetőségekröl írnék, érdemes körüljárni az alapvető tanulási mechanizmusokat. Explicit (tudatos figyelmet igénylö) módon tanítva őket nem teljesítenek jól az autizmussal élő személyek: előzetes tanítást követő utasításra képesek lehetnek megfelelö feladatvégzésre, de hosszabb késleltetés (pl. 20 órás késleltetés) után már nem biztos, hogy ugyanolyan sikerességgel végrehajtják az explicit müveleteket (Dawson, Mottron és Gernsbacher, 2008). A számítógéppel való tanítás hatékonyan támogathatja öket (Moore, McGrath és Thorpe, 2000). Korábbi vegyes eredményeket hozó vizsgálatok után 2010-es tanulmányuk autizmussal élö személyeknél implicit (tudatos figyelmet nem igénylő, készségszintü tanulási) feladaton ép, a tipikusan fejlődő személyekével megegyező teljesítményt talált. Az implicit tanulási készség öntudatlan, statisztikai tulajdonságaival a motoros készségeknek, a kognitív és szociális készségeknek egyaránt alapjául szolgál. A fenti eredmény arra enged következtetni, hogy az autista gyerekek az implicit tanulás alatt elsajátított készséget hosszú időn keresztül is tudják tárolni (Németh, Janacsek, Balogh, Londe, Mingesz, Fazekas, Jámbori, Dányi és Vetró, 2010; magyarul ld. Balogh, 2010).

A terápiák felől megközelítve az autizmussal élők fejlesztését több csoportba sorolhatjuk. Léteznek ún. biomedikális terápiák, melyek a toxikus anyagokkal való érintkezést kívánják mérsékelni. Feltételezések szerint az autizmusra „hajlamosító” genetikai faktorok nem mindig hozzák felszínre a zavart önmagában (Siri és Lyons, 2010), ám bizonyos toxikus anyagokkal való érintkezés hatására megjelennek, erőteljesebbé válnak. A korai intervenció vonatkozásában hozhat érdemi gondolatokat a megközelítés. 
Gyógyszeres kezelés antipszichotikumok segítségével elsősorban a repetitív viselkedés csökkentésére, a szelektív szerotoninvisszavétel-gátlók szintén a repetitív viselkedéses tünetek, valamint az agitációs állapot kezelésére, a stimulánsok pedig a hiperaktív-figyelemhiányos tünetek, illetve az irritabilitás kezelésére használhatók (Lai és mtsai, 2014). Részletesebben szólnék a viselkedéses/oktató jellegü, döntően pszichológiai eljárásokról. A terápiák négy területet céloznak: a szociális és kommunikációs területek támogatását, a tanulási és problémamegoldó készségek fejlesztését, a tanulási nehézségeket indukáló viselkedésformák mérséklését, valamint az autizmussal élő személy családjának támogatását (Rutter, 1985).

Elsőként szólnék a komprehenzív, több vezető tünetet megcélzó programokról (Callahan, Shukla-Mehta, Magee és Wie, 2010). Léteznek viselkedéses programok, a Lovaas-módszerre, illetve az ABA-módszerre (Applied Behavior Analysis) épülve. A Dr. Ivar Lovaas nevéhez köthetö Lovaas-program (Maglione, Gans, Das, Timbie és Kasari, 2012) az alkalmazott viselkedéselemzés elveire építve föként a nyelvi és társas kapcsolatok fejlesztését célozta meg egy, a szülőket és kortársakat is bevonó fejlesztő munka keretében.

Fiatal, 5 év alatti gyermekek számára az ABA-alapú, intenzív viselkedéses eljárások használhatók, melyek otthoni és intézményi keretek között alkalmazandóak, egyszerü, strukturált lépésekben tanítva a gyermekeket. A fejlesztés többnyire minden területre kiterjed, így tartalmaz többek között szociális-kommunikatív készségfejlesztést, foglalkozik a szociális figyelem és motiváció témakörével, illetve magában foglal utánzás-alapú interperszonális fejlesztést, self-managementet (Lai és mtsai, 2014). Tartalmaz viselkedéselemzést, a környezeti tényezők elemzését, ezeket felhasználva tanítja új viselkedésre a gyermeket. Mindkét módszer heti 20-40 órában, 1-4 éven át célravezető.

A környezet támogatására is nagy hangsúlyt fektető TEACCH programot (Treatment Education of Autistic and Related Communication-Handicapped Children) nagyobb gyermekek, illetve felnőttek részére dolgozták ki (Maglione és mtsai, 2012). Átfogó, strukturált eszköz, melyet Schopler és munkatársai fejlesztettek ki az 1970-es években (Schopler, 1994). Az eljárás épít az egyéni relatív erősségre (vizuális képesség, érdeklődés terén), ezt használja a tanulás megvalósításához, melynek során alapvető mind a környezet, mind magának az aktivitásnak a magas fokú strukturáltsága (Lai és mtsai, 2014). A módszer intenzív, többféle szolgáltatást biztosít mind az autizmussal élő személy, mind az érintett család számára a diagnosztika, tanácsadás, fejlesztő játékok és szülötréning formájában. A megközelítés főbb vonatkozásai: az alkalmazkodás növelése, szülői együttmüködés támogatása, egyénre szabott kezelés, strukturált oktatás, készségek erősítése, kognitív viselkedés terápia (Panerai, Zingale, Trubia, Finocchiaro, Zuccarello, Ferri és Elia, 2009). Négy fő komponens jelenik meg a kezelés során: a fizikai környezet strukturálása, vizuális ütemterv (,órarend”, mit, mikor fog csinálni), munkarend (mit és hogyan kell csinálni), feladatszervezés (Schopler, 1994). A program hatékonyságát számos tanulmány vizsgálta már, Panerai és munkatársai a TEACCH, valamint egy nem autizmus-specifikus inkluzív nevelési eljárás hatékonyságát vetették össze. Eredményeik szerint a TEACCH szignifikánsan hatékonyabbnak bizonyult (Panerai és mtsai, 2009).

Léteznek speciális tréningek, melyek a hétköznapi életkészségek, illetve az autonómia területén (Training in living skills and autonomy) kívánnak segítséget nyújtani az érintetteknek (Maglione és mtsai, 2012). Illetve van kifejezetten szakmai irányú intervenciót adó tréning (Vocational intervention) is, mely interjúhelyzetekkel támogatja a munkavállalást (Lai és mtsai, 2014).. A video-modellezés is ígéretes lehetőségeket kínál, ennek egy speciális formája (VSM, Video self-modeling) során a gyerekek egy szerkesztett videót néznek, melyben vagy egy adott készség végrehajtását, vagy egy kívánt célviselkedést láthatnak. Lehetséges egyfajta „elővételezés” ('feedforward'), amikor egy olyan készséget vagy viselkedést jelenít meg a videón valaki, mely a gyermek képességhatárain belül van; vagy lehetséges a saját viselkedés pozitív áttekintése, megerösítése ('positive 
self-review’), amikor egy már megjelent készség gyakoriságának növekedését várjuk a videó által (Love, 2014).

A fejlesztési lehetőségek egy másik csoportja az érintett személy környezetét is aktívan bevonja a programba, kifejezetten kisgyermekek és családjaik számára készült a lehetőség. Szülö-mediált korai intervenciót (Training for joint attention, parent-child interaction, and communication; or models like pivotal response training, parent delivery of the ESDM, and More Than Words) biztosítanak, például a közös figyelem, a kommunikáció, a megfelelő modellálás fejlesztése, tanítása a cél a szülők, gondozók számára, rajtuk keresztül pedig a gyermek számára (Lai és mtsai, 2014). A PCIT (Parent Child Interaction Therapy) a magatartás-problémák csökkentését célozza meg (Masse, 2010).

A viselkedéses intervenciók egy másik csoportja kifejezetten a szorongás, illetve az agresszió kezelését célozza meg: mivel autizmusban ezek gyakran vezető problémaként jelennek meg, ezért ezeket külön is említem. Kognitívviselkedés-terápiás, illetve ABA módszerek segítségével dolgoznak. Előbbit a szorongás oldására, a diszfunkcionális gondolatok azonosításával, adaptív készségek tanításával, konkrét instrukciók segítségével, illetve olykor a szisztematikus deszenzitizáció eszközével. Az ABA módszer az agresszió csökkentését kívánja elérni, funkcionális viselkedésegyüttes-értékeléssel, alternatív viselkedések tanításával, továbbá a maladaptív viselkedést leépítő stratégiákkal dolgozva (Lai és mtsai, 2014).

Callahan és munkatársai (2010) vizsgálata szerint szociális validitás szempontjából azok az autizmus-specifikus kezelési komponensek, melyek mind az ABA, mind a TEACCH megközelítésében egyaránt szerepelnek, jóval erősebbek, mint bármely más komponens, függetlenül attól, hogy a fenti két program melyikének képezik részét. Léteznek olyan integratív eljárások is, melyek több, fenti módszer elemeit ötvözik, így például kombinálják a TEACCH és az ABA programot. Integratív eljárás a STAR (Young, 2006) vagy a Walden Toddler Program (McGee, Morrier és Daly, 1999).

Az alábbiakban a limitált nyelvi készséggel vagy nyelvi készség nélkül élö autizmussal élő gyermekek számára kifejlesztett intervenciós lehetőségekről írok. A célzott készség-alapú intervenciók közül a Képkártyacsere-módszer (Picture Exchange Communation System, PECS) a kommunikációs- és tanulási nehézségek mérséklésére kidolgozott, életkorfüggetlen módszer (Maglione és mtsai, 2012). A funkcionális kommunikáció oktatására dolgozták ki, alapvetően nem verbalizáló autizmussal élők számára. Az eljárás szimbólumok és képek segítségével hivatott akár a spontán verbális kommunikáció sikeres elsajátítását elérni (Lai és mtsai, 2014). A módszert különböző kutatások eltérő hatékonyságúnak találták, általában rövid távon több pozitív vonatkozással, míg hosszabb távon kevesebbel (Maglione és mtsai, 2012). Emellett léteznek más alternatív kommunikációs eljárások is, például az AAC (Augmentative and Alternative Communication), illetve auditoros integrációs trénig is rendelkezésére áll az érdeklődőknek (Maglione és mtsai, 2012). Gyermekek számára fejlesztettek ki egy viszonylag rövid (néhány hetet, hónapot felölelö) tréninget (Training in joint attention, pretend play, socially synchronous behaviour, imitation, emotion recognition, theory of mind, and functional communication), mely a közös figyelem, szerepjáték, szociális szinkron-viselkedés, utánzás, érzelem-felismerés, tudatelmélet, valamint a funkcionális kommunikáció fejlesztésére szolgál (Lai és mtsai, 2014).

Több program kifejezetten a szociális készségek fejlesztését célozza meg (Social skill training), hangsúlyt fektetve a kortárs kapcsolatokra, valamint a közös figyelemre (Kasari és Patterson, 2012). Bizonyos programokat bármely életkori övezetben javasolt használni, rövid lefutású programként (Maglione és mtsai, 2012), DVD-k segítségével (pl. Mindreading, The Transporters) igyekszik a szociális készségeket (pl. az érzelem-felismerést) fejleszteni. Egy másik tréning (pl. Lego therapy) csoportos formában müködik, 6 éves kortól szól, és szintén rövid távú programot kínál (Lai és mtsai, 2014). 
Néhány további lehetőségről is szólnék röviden, melyek érdekesek lehetnek. Gray a „Szociális történetek” kidolgozója: rövid, írott szövegeken keresztül igyekszik hétköznapi élethelyzeteket megértetni az autizmussal élőkkel, segíteni a szociális jelzések azonosítását, gyakorolni egyes helyzeteket, korrigálni rosszul sikerült társas epizódokat (Gray és Garand, 1993). A magyar Autizmus Kutatócsoport fejlesztette ki az ún. Babzsák programot (Öszi, Balázs, Szaffner, Gosztonyi és Korpás, 2007), mely játékos helyzetben teszi lehetővé a kommunikációs, szociális foglalkozásokat. A módszer ötvözi a hétköznapi élethelyzetek, az egyéni fejlesztés, a frontális oktatás elemeit, nagy hangsúlyt adva a játékkészségnek is. Az egyéni adottságokhoz való igazodás révén a differenciális fejlesztésre is lehetőséget biztosít.

A Szenzoros integrációs terápiák (Sensory Integration Therapy, SIT, Ayres terápia; Ayres, 1979) és Alapozó terápiák, Multiszenzoros integrációs terápiák (Howlin, 2004) a szenzoros diszfunkciók kezelését célozzák meg, több modalitást érintő ingerek segítségével (pl. tapintás, proprioceptív érzékelés, egyensúly), nem autizmus-specifikus kezelésként. A Deszenzitizációs eljárás a szenzoros tevékenységekbe való bevonás révén az egyre adaptívabb cselekvések megjelenését kívánja elérni (Bogashina, 2003). Az Alapozó terápia a fejlődésben elmaradott gyermekek idegrendszeri felzárkóztatását tüzi ki célul (Marton-Dévényi, Szerdahelyi, Tóth és Keresztesi, 2005).

A Helping Autism-diagnosed teenagers Navigating and Developing Socially (HANDS) a társas eligazodásban, társadalmi helyzetekben, szociális fejlődésben, önállósodásban nyújt új lehetőségeket, egyénre szabott módon, autizmussal élő serdülők (10-18 évesek) számára (részletesebb lásd: Mintz, Győri és Aagaard, 2012). A módszer egy kognitív támogató eszközrendszer, melynek fö funkciója egy mobil eszközön futó alkalmazás, ami folyamatosan rendelkezésére áll az érintettnek. Közvetíti a szükséges információkat, segíti a kritikus helyzetekben való eligazodást. Továbbá explicit instrukciók révén tanító szereppel is bír, illetve alkalmazza a tanulást megerősítő jutalmazást is (Győri, Kanizsai-Nagy és Stefanik, 2011).

Az alábbi eljárások hatékonyságára vonatkozóan nemzetközi kitekintésben nem találtam releváns adatokat, mivel azonban a gyakorlatban olykor használják öket (főként kiegészítő eljárásként), röviden említést teszek róluk. E módszerek értékeléséről Howlin (2004) ír: többségében nem autizmus-specifikus, nem ártalmas, gyakran az adott terápia „kellemes” jellege miatt sikerrel kecsegtető, de bizonyított hatékonysággal nem rendelkező módszernek említi őket.

A művészetterápiák középpontjában a nonverbalitás áll, mely ilyen módon érthetővé teszi a módszer alkalmazásának relevanciáját autizmus esetén. Az eljárások segíthetik az imaginatív, absztrakciós gondolkodás, szenzoros szabályozás és integráció, érzelemmegértés, önkifejezés, vizuális-térbeli képességek fejlődését, valamint segíthetik a rekreációs tevékenység adekvát kiválasztását és a művészi növekedést (Martin és Betts, 2010).

Az állatasszisztált terápiák (Animal-Assisted Inventions), így a kutyaterápia, valamint a lovasterápia többek között a szociális, kommunikációs területeken segíthetnek gátakat átlépni (Fine, 2010), nem fenyegető módon ösztönzik a résztvevőt, támogatják az empátia fejlődését. A hidroterápia az autoagresszivitás csökkentését, a mozgáskoordináció fejlesztését tudja facilitálni, a drámaterápia pedig az érzelemmegértés, magatartás-korrekció, szociális interakciók fejlődése vonatkozásában lényeges (Bailey, 2010).

Összefoglalva: a terápiás lehetőségek terén a nemzetközi konszenzus minél korábbi kezdetet, továbbá erősen strukturált, intenzív, kognitív viselkedéses megközelítést javasol, megjegyezve azt, hogy az eredményesség fokát számos tényező befolyásolja (NAPC, 2003; Csepregi, Horvát és Simó, 2011).

Az autizmus felfedezése óta számos kérdésre született meg a válasz, egyre többet tudunk e témában. Dolgozatomban az autizmus jellemzőinek és modelljeinek áttekintésén túl megpróbáltam bepillantást adni a terápiás lehetőségekbe is. Azonban jelenleg is 
vannak még megvilágítatlan területek, folynak kutatások, melyek mind azzal a reménynyel kecsegtetnek, hogy az autizmus kirakójátékában a még mindig hiányzó darabok egyszer helyükre kerülnek.

\section{Irodalomjegyzék}

APA $(1980)=$ American Psychiatric Association (1980): Diagnostic and Statistical Manual of Mental Disorders. 3th ed. Author, Washington, DC.

APA (1994) = American Psychiatric Association (1994): Diagnostic and Statistical Manual of Mental Disorders. 4th ed. Author, Washington, DC.

APA (2013) = American Psychiatric Association (2013): Diagnostic and Statistical Manual of Mental Disorders. 5th ed. Author, Arlington, VA. DOI: 10.1176/appi.books.9780890425596.893619

Asberg, J., Kopp, S., Berg-Kelly, K. és Gillberg, C. (2010): Reading comprehension, word decoding and spelling in girls with autism spectrum disorders (ASD) or attention-deficit/hyperactivity disorder $(\mathrm{AD} / \mathrm{HD})$ : performance and predictors. International Journal of Language and Communication Disorders, 45. 61-71. DOI: 10.1080/13682820902745438

Asperger, H. (1944): Die „Autistischen Psychopathen” im Kindesalter. European Archives of Psychiatry and Clinical Neuroscience, 117. 1. sz. 76-136. DOI: 10.1007/bf01837709

Ayres, J. (1979): Sensory Integration and the Child. Western Psychological Services, Los Angeles, CA.

Bailey, S. (2010): Drama Therapy. In: Siri, K. és Lyons, T. (szerk..): Cutting-Edge Therapies for Autism 2010-2011. Skyhorse Publishing, New York, NY. 124-127.

Bailey, A., Phillips, W. és Rutter, M. (1996): Autism: Towards an integration of clinical, genetic, neuropsychological and neurobiological perspectives. Journal of Child Psychology and Psychiatry, 37. 89-126. DOI: 10.1111/j.1469-7610.1996.tb01381.x

Balogh Virág (2010): Készségtanulás autizmusban. In: Kozma T. és Perjés I. (szerk.): Új Kutatások a Neveléstudományokban 2009. Többnyelvüség és multikulturalitás. Aula Kiadó, Budapest.

Baron-Cohen, S. (1995): Mindblindness: An essay on autism and theory of mind. MIT Press, Cambridge, Mass.

Baron-Cohen, S. és Bolton, P. (2000): Autizmus. Osiris Zsebkönyvtár, Budapest.

Baron-Cohen, S., Leslie, A. M. és Frith, U. (1985): Does the autistic child have a theory of mind? Cognition, 21. 37-46. DOI:_10.1016/00100277(85)90022-8

Baron-Cohen, S., Wheelwright, S., Hill, J., Raste, Y. és Plumb, I. (2001): The „Reading the Mind in the Eyes". Test Revised Version: A Study with Normal Adults, and Adults with Asperger Syndrome or High- functioning Autism. Journal of Child Psychology and Psychiatry, 42. 241-251. DOI: 10.1111/1469. 7610.00715

Bogdashina, O. (2003): Sensory Perceptual Issues in Autism and Asperger Syndrome. Different Sensory Experiences. Different Perceptual Worlds. Jessica Kingsley Publishers, London, England.

Brüne, M. és Brüne-Cohrs, U. (2006): Theory of mind - evolution, ontogeny, brain mechanisms and psychopathology. Neuroscience and Biobehavioral Reviews, 30. 437-455. DOI: 10.1016/j. neubiorev.2005.08.001

Burack, J. A., Enns, J. T., Stauder, J. E. A., Mottron, L. és Randolph, B. (1997): Attention and autism: Behavioral and electrophysiological evidence. In: Cohen, D. J. és Volkman, F. R. (szerk.): Handbook of autism and pervasive developmental disorders. John Wiley \& Sons Inc., Hoboken, NJ. 226-247.

Callahan, K., Shukla-Mehta, S., Magee, S. és Wie, M. (2010): ABA versus TEACCH: the case for defining and validating comprehensive treatment models in autism. Journal of Autism and Developmental Disorders, 40. 74-88. DOI: 10.1007/s10803-0090834-0

Csepregi A., Horvát K. és Simó J. (2011): Az autizmus spektrumzavarok szürési-diagnosztikai modellje. Fogyatékos Személyek Esélyegyenlőségéért Közalapítvány.

Csibra, G., Gergely, G., Biro, S., Koos, O. és Brockbank, M. (1999): Goal attribution without agency cues: the perception of 'pure reason' in infancy. Cognition, 72. 3. sz. 237-267. DOI: 10.1016/ s0010-0277(99)00039-6

Csíkszentmihályi, M. (1990): Flow: the psychology of optimal experience. Harper and Row, New York, NY.

Dawson, G. és Castelloe, P. A. (1992): Autism. In: Walker, C. E. és Roberts, M. C. (szerk.): Handbook of Clinical Child Psychology. 3. Ed. John Wiley \& Sons Inc., New York - Toronto. 375-397.

Dawson, M., Souliéres, I., Mottron, L. és Gernsbacher, M. A. (2007): The level and nature of autistic intelligence. Psychological Science, 18. 8. sz. 657-662. DOI: 10.1111/j.1467-9280.2007.01954.x

Dawson, M., Mottron, L. és Gernsbacher, M. A. (2008): Learning in autism. In: Byrne, J. H. és Roediger, H. (szerk.): Learning and memory: A comprehensive reference: Cognitive Psychology. Elsevier, New York. 759-772. 
Deary, I. J., Penke, L. és Johnson, W. (2010): The neuroscience of human intelligence differences. Nature Review Neuroscience, 11. 201-211. DOI: 10.1038/nrn2793

Fine, A. (2010): Animal-Assisted Interventions and Persons with Autism Spectrum Disorders. In: Siri, K. és Lyons, T. (szerk.): Cutting-Edge Therapies for Autism 2010-2011. Skyhorse Publishing, New York, NY. 10-16.

Fletcher, P. C., Zafiris, O., Frith, C. D., Honey, R. A., Corlett, P. R., Zilles, K. és Fink, G. R. (2005): On the benefits of not trying: brain activity and connectivity reflecting the interactions of explicit and implicit sequence learning. Cerebral Cortex, 15. 1002-1015. DOI: $10.1093 /$ cercor/bhh201

Fogassi, L., Gesierich, B., Rizzolatti, G., Rozzi, S., Chersi, F. és Ferrari, P. F. (2005): Parietal Lobe: From Action Organization to Intention Understanding. Science, 308. 5722. sz. 662-667. DOI: 10.1126/ science. 1106138

Freitag, C. M., Luders, E., Hulst, H. E., Narr, K. L., Thompson, P. M., Toga, A. W., Krick, C. és Konrad, C. (2009): Total brain volume and corpus callosum size in medication - naïve adolescents and young adults with autism spectrum disorder. Biological Psychiatry, 66. 316-319. DOI: $10.1016 / \mathrm{j}$. biopsych.2009.03.011

Frith, C. D. és Frith, U. (1991): Elective Affinities in Schizophrenia and Childhood Autism. In: Bebbington, P. E. (szerk.): Social Psychiatry: Theory, Methodology, and Practice. Transaction Publishers, New Brunswick. 65-88.

Frith, U. (1998): What autism teaches us about communication. Logopedics, Phoniatrics and Vocology, 23.51-58.DOI: 10.1080/140154398434194

Frith, U., Firth, C.D. (2003): Development and neurophysiology of mentalizing. Philosophical Transactions of the Royal Society, London, 358. 1431. Sz. 459-473. DOI: 10.1098/rstb.2002.1218

Frith, U., Morton, J. és Leslie, A. M. (1991): The cognitive basis of a biological disorder: Autism. Trends in Neurosciences, 14. 10. sz. 433-438. DOI: 10.1016/0166-2236(91)90041-r

Gardener, H., Spiegelman, D. és Buka, S. L. (2011): Prenatal and neonatal risk factors for autism: comprehensive meta-analysis. Pediatrics, 128. 2. 344-355. DOI: 10.1542 /peds.2010-1036

Geschwind, D. H. (2011): Genetics of autism spectrum disorders. Trends in Cognitive Sciences, 15. 409-16. DOI: 10.1016/j.tics.2011.07.003

Gopnik, A. és Aslington, J. W. (1988): Children's understanding of representational change and its relation to the understanding of false belief and the appearance-reality distinction. Child Development, 59. 1. sz. 26-37. DOI: $10.1111 / \mathrm{j} .1467-8624.1988$. tb03192.x
Gopnik, M. (1994): The auditory perception/ processing hypothesis revisited. In: Special issue of the McGill working papers in linguistics: Linguistic aspects of familial language impairment. McGill University, Montreal. X. 135-141.

Gopnik, A., Slaughter, V. és Meltzoff, A. (1994): Changing your views: How understanding visual perception can lead to a new theory of mind. In: Lewis, Ch. és Mitchell, P. (szerk.): Children's Early Understanding of Mind: Origins and Development. Lawrence Erlbaum Associates, Publishers, Hova (UK) - Hillsdale (USA). 157-181. DOI: 10.4324/9781315804668

Gopnik, A. és Wellman, H. M. (1994): The theory theory. Mapping the mind: Domain specificity in cognition and culture, 257-293.

Gray, C. és Garand, J. D. (1993): Social Stories: Improving Responses of Students with Autism with Accurate Social Information. Focus on Autism and Other Developmental Disabilities, 8. 1-10. DOI: 10.1177/108835769300800101

Győri Miklós (2003): A neurokognitív fejlődés moduláris zavarai: az autizmus. In: Pléh Csaba, Kovács Gy. és Gulyás B. (szerk.): Kognitiv idegtudomány. Osiris Kiadó, Budapest. 738-759.

Győri Miklós, Gy. Stefanik K., Kanizsai-Nagy Ildikó és Balázs Anna (2002): Naiv tudatelmélet és nyelvi pragmatika magasan funkcionáló autizmusban: reprezentációs zavar, performancia korlát, vagy kompenzáció? In: Racsmány M., Kéri Sz. és Pléh Csaba (szerk.) Architektúra és patológia a megismerésben. Osiris Kiadó, Budapest. 11-39. o.

Győri Miklós (2009): A naiv tudatelméleti képesség változatossága autizmusban-és implikációi az atipikus megismerésre és tanulásra nézve. Gyógypedagógiai Szemle, 2. sz. 96-111.

Győri Miklós (2012): Pervazív fejlődési zavarok: az autizmus spektrum. In: Bereczkei Tamás és Hoffman Gyula (szerk.): Gének, gondolkodás, személyiség. Akadémiai Könyvkiadó, Budapest.

Győri, Miklós, Kanizsai-Nagy Ildikó és Stefanik K. (2011): Miért nélkülözhetetlen a komlex empirikus kutatásmódszertan? Integrált eredmények és érvek a HANDS projektről. In: Hegedüs Judit, Kempf Katalin és Németh András (szerk.) Közoktatás, pedagógusképzés, neveléstudomány - a múlt értékei és a jövő kihívásai. 11. Országos Neveléstudományi Konferencia, Budapest, 2011. 11. 03. - 2011. 11. 05. 483.

Happé, F. (1993): Communicative competence and theory of mind in autism: A test of relevance theory. Cognition, 48. 101-119. DOI: 10.1016/00100277(93)90026-r

Happé, F. (1994a): An advanced test of theory of mind: Understanding of story characters' thoughts and feelings by able autistic, mentally handicapped and normal children and adults. Journal of Autism 
and Developmental Disorders, 24. 129-154. DOI: $10.1007 / \mathrm{bf0} 2172093$

Happé, F. (1994b): Autism: an Introduction to Psychological Theory. Harvard University Press, Cambridge, MA.

Happé, F. és Charlton, R. A. (2012): Aging in Autism Spectrum Disorders: A Mini-Review. Gerontology, 58. 70-78. DOI: 10.1159/000329720

Happé, F. és Vital, P. (2009): What aspects of autism predispose to talent? Philosophical Transactions of The Royal Society, Biological Sciences, 364. 1369-1375. DOI: 10.1098/rstb.2008.0332

Howlin, P. (2004): Autism and Asperger syndrome Preparing for Adulthood. Routledge, London.

Janetzke, H. (1995): Autizmus. Élmény Könyvkiadó, Hajdúhadháza.

Jordan, R. (2007): Autizmus társult értelmi sérüléssel. Kapocs Könyvkiadó, Budapest. 118-141.

Kanner, L. (1946): Irrelevant and metaphorical language in early infantile autism. American Journal of Psychiatry, 103. 242-246. DOI: 10.1176/ ajp.103.2.242

Karmiloff-Smith, A. (1991): Beyond modularity: Innate constraints and developmental change. In: Carey, S. és Gelman, R. (szerk.): The epigenesis of mind: Essays on biology and cognition. Lawrence Erlbaum Associates, Hillsdale, NJ. 171-197. DOI: $10.4324 / 9781315807805$

Kasari, C. és Patterson, S. (2012): Interventions addressing social impairment in autism. Current Psychiatry Reports, 14. 713-25. DOI: 10.1007/ s11920-012-0317-4

Korkmaz, B. (2011): Theory of Mind and Neurodevelopmental Disorders of Chilhood, Pediatric Research, 69. 101-108. DOI: 10.1203/ pdr.0b013e318212c177

Lai, M-C., Lombardo, M. V. és Baron-Cohen, S. (2014): Autism. The Lancet, 383. 9920. sz. 896-910. DOI: 10.1016/s0140-6736(13)61539-1

Love, D. (2014): The Effectiveness of Video SelfModeling to TEACH play and adaptive skills to a young preschooler with developmental disabilities. In: Masters Theses and Doctoral Dissertations. The University of Tennessee at Chattanooga, Chattanooga, TN.

Lord, C. és Rutter, M. (1994): Autism and pervasive developmental disorders. In: Rutter, M., Taylor, E. és Hersov, L. (szerk.): Child and Adolescent Psychiatry: Modern Approaches. 3rd ed. Blackwell, Cambridge. 569-593.

Lord, C., Rutter, M., Dilavore, P. C. és Risi, S. (1999): Autism Diagnostic Observation Schedule. Western Psychological Services, Los Angeles.

Maglione, M. A., Gans, D., Das, L., Timbie, J. és Kasari, C. (2012): Nonmedical interventions for children with ASD: recommended guidelines and further research needs. Pediatrics, 130. 2. sz. 169 178. DOI: 10.1542 /peds.2012-0900o

Masse, J. (2010): Autism spectrum disorders. In: McNeil, C. B. és Hembree-Kigin, T. L. (szerk.): Parent-Child Interaction Therapy. Springer US, New York, NY. 237-254.

Martin, N. és Betts, D. (2010): Art therapy approaches to treating autism. In: Siri, K. és Lyons, T. (szerk.): Cutting-Edge Therapies for Autism 2010-2011. Skyhorse Publishing, New York, NY. 48-52.

Marton-Dévényi, É., Szerdahelyi, M., Tóth, G. és Keresztesi, K. (2005): Alapozó Terápia. Alapozó Terápiák Alapítvány, Budapest.

McGee, G. G., Morrier, M. J. és Daly, T. (1999): An incidental teaching approach to early intervention for toddlers with autism. Journal of the Association for Persons whit Several Handicaps, 24. 133-146. DOI: 10.2511/rpsd.24.3.133

Mesibov, G., Thomas, J. B., Chapman, M. és Schopler, E. (2007): Teacch Transition Assessment Profile. Pro Ed, Austin, TX.

Minshew, N. J. és Keller, T. A. (2010): The Nature of Brain Dysfunction in Autism: Functional Brain Imaging Studies. Current Opinion in Neurology, 23. 2.sz.124-130.DOI: 10.1097/wco.0b013e32833782d4

Mintz, J., Győri, M. és Aagaard, M. (2012): Touching the Future Technology for Autism: Recommandations. In: Mintz, J., Győri, M. és Aagaard, M. (szerk.): Touching the Future Technology for Autism? Lessons from the HANDS Project. IOS Press, Amsterdam. 117-131.

Moore, D., McGrath, P. és Thorpe, J. (2000): Computer-aided learning for people with autism - a framework for research and development. Innovations in education and training international, 37. 218-228. DOI: $10.1080 / 13558000050138452$

NAPC (2003): Plan for the Identification, Assessment, Diagnosis and Access to early interventions for preschool and primary-school aged children with Autism Spectrum Disorder (ASD). The National Autistic Society for NIASA in collaboration with The Royal College of Psychiatrists (RCPsych), The Royal College of Pediatrics and Child Health (RCPCH), All Party Parliamentary Group on Autism (APPGA)

Németh, D., Janacsek, K., Balogh, V., Londe, Zs., Mingesz, R., Fazekas, M., Jámbori, Sz., Dányi, I. és Vetró, Á. (2010): Learning in Autism: implicitly superb. Public Library of Science, 5. 7. sz. 1-7. DOI: 10.1371/journal.pone.0011731

Ozonoff, S. (1997): Components of executive function in autism and other disorders. In: Russell, J (szerk.): Autism as an executive disorder. Oxford University Press, Oxford. 179-211. DOI: 10.1093/ med:psych/9780198523499.001.0001 
Öszi, P., Balázs, A.., Szaffner, É., Gosztonyi, N. és Korpás, D. (2007): Autism specific socialcommunication small group activity: the beanbag. Poster presentation: 8th International Congress Autism Europe, Oslo, Norway.

Panerai, S., Zingale, M., Trubia, G., Finocchiaro, M., Zuccarello, R., Ferri, R. és Elia, M. (2009): Special Education Versus Inclusive Education: The Role of the TEACCH Program. Journal of Autism and Developmental Disorders, 39. 6. 874-882. DOI: 10.1007/s10803-009-0696-5

Peeters, T. (1997): Autism: From theoretical understanding to educational intervention. Whurr Publishers, London.

Reber, A. S. (1976): Implicit learning of synthetic languages: the role of instructional set. Journal of Experimental Psychology Human Learning and Memory, 2. 88-94. DOI: 10.1037//0278-7393.2.1.88

Redcay, E. és Courchesne, E. (2005): When is the brain enlarged in autism? A meta-analysis of all brain size reports. Biol Psychiatry, 58. 1. sz. 1-9. DOI: 10.1016/j.biopsych.2005.03.026

Rizzolatti, G. és Arbib, M. A. (1998): Language within our grasp. Trends in Neurosciences, 21. 5. sz. 188-194. DOI: 10.1016/s0166-2236(98)01260-0

Robbins, T., McAlonan, G., Muir, J. és Everitt, B. (1997): Cognitive enhancers in theory and practice: Studies of the cholinergic hypothesis of cognitive deficits in Alzheimer's disease. Behavioural Brain Research, 83. 1-2. sz. 15-23. DOI: 10.1016/s01664328(97)86040-8

Roelfsema, M. T., Hoekstra, R. A. és Allison, C. (2012): Are autism spectrum cinditions more prevelant ina $\mathrm{n}$ information-technology region? Aschool-based study of three regions in Netherlands. Journal of Autism Developmental Disorders, 42. 734739. DOI: 10.1007/s10803-011-1302-1

Rommelse, N. N. J., Geurts, H. M., Franke, B., Buitelaar, J. K. és Hartman, C. A. (2011): A review on cognitive and brain endophenotypes that may be common in autism spectrum disorder and attentiondeficit/hyperactivity disorder and facilitate the search for pleiotropic genes. Neuroscience and Biobehavioral Reviews, 10. 1016.

DOI: 10.1016/j.neubiorev.2011.02.015

Rutter, M. (1985): Infantile autism. In: Schaffer, D., Erhardt, A. és Greenhill, L. (szerk.): A Clinician's Guide to Child Psychiatry. Free Press, New York, NY. 47-78.

Rutter, M. (1966): Prognosis: Psychotic children in adolescence and early adult life. In: Wing, J. K. (szerk.): Childhood autism: Clinical, educational, and social aspects. Pergamon Press, Elmsford, NY.

Schopler, E. (1994): A statewide program for the treatment and education of autistic and related communication handicapped children (TEACCH). Psychoses and Pervasive Developmental Disorders, 3. 91-103.

Schopler, E., Reichler, R., Bashford, A., Lansing, M. és Marcus, L. (1990): Individualized assessment and treatment for autistic and developmentally disabled children: Vol. l. Psychoeducational profile revised (PEP-R). Pro Ed, Austin, TX.

Schuman, C. M., Noctor, S. C. és Amaral, D. G. (2011): Neuropathology of autism spectrum disorders: postmortem studies In: Amaral, D. G., Dawson, G. és Geschwind, D. H. (szerk.): Autism spectrum disorders. Oxford University Press, New York, NY. 539-565.

DOI: $10.1093 / \mathrm{med} / 9780195371826.001 .0001$

Sinzig, J., Morsch, D., Bruning, N., Schmidt, M. H. és Lehmkuhl, G., (2008): Inhibition, flexibility, working memory and planning in autism spectrum disorders with and without comorbid ADHD symptoms. Child Adolescent Psychiatry and Mental Health, 2. 4. sz. DOI: 10.1186/1753-2000-2-4

Siri, K. és Lyons, T. (2010): Cutting-Edge Therapies for Autism 2010-2011. Skyhorse Publishing, New York, NY.

Várnagy, Zs., Győri, M. és Bérdi, M. (2011): A megismerés modellezése autizmusban: A konnekcionista (mesterséges neuronhálózatos) szimulációk rövid áttekintése. Magyar Pszichológiai Szemle, 66. 2. sz. $335-360$.

Williams, D. és Happé, F. (2009): 'What did I say?' versus 'What did I think?': attributing false beliefs to self amongst children with and without autism. Journal of Autism and Developmental Disorders, 39. 865-873. DOI: 10.1007/s10803-009-0695-6

Wimmer, H. és Perner, J. (1983): Beliefs about beliefs: Representation and constraining function of wrong beliefs in young children's understanding of deception. Cognition, 13. 103-128. DOI: 10.1016/0010-0277(83)90004-5

WHO (1992) = World Health Organization (1992): International classification of diseases: Diagnostic criteria for research. 10th ed. Author, Geneva, Switzerland.

Woolfenden, S., Sarkozy, V., Ridley, G., Coory, M. és Williams, K. (2012): A systematic review of two outcomes in autism spectrum disorder - epilepsy and mortality. Developmental Medicine and Child Neurology, 54. 306-312. DOI: 10.1111/j.1469-8749.2012.04223.x

Young, H. (2006): An Examination of the Variables That Affect the Outcomes of Children With Autism Spectrum Disorders. Portland State University, Portland, OR. 